\title{
Features of the physical oceanographic conditions of the Barents Sea
}

\author{
HARALD LOENG
}

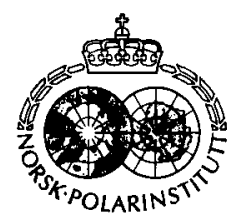

Loeng, H. 1991: Features of the physical oceanographic conditions of the Barents Sea. Pp. 5-18 in Sakshaug, E., Hopkins, C. C. E. \& Øritsland, N.A. (eds.): Proceedings of the Pro Mare Symposium on Polar Marine Ecology. Trondheim, 12-16 May 1990. Polar Research 10(1).

The Barents Sea is a shallow continental shelf sea. Generally, the physical conditions are determined by three main water masses: Coastal Water, (North) Atlantic Water, and Arctic Water. These three water masses are linked to three different current systems: the Norwegian Coastal Current, the Atlantic Current, and the Arctic Current. This paper gives a brief description of these current systems and their related water masses. Vertical stratification of the different water masses is emphasised since this is important for primary production.

Climatic variability is determined by the properties and the activity of the inflowing Atlantic Water. Current activity variations may be explained by external forcing. but may also be a result of processes taking place in the Barents Sea itself. The climatic fluctuations have a significant effect on the ice conditions, which in turn influence the biological production in the northern Barents Sea

Harald Loeng, Institute of Marine Research, P.O. Box 1870 Nordnes, N.5024 Bergen. Norway.

\section{Introduction}

In order to understand the biological production processes that take place in the ocean, it is important to have knowledge of the physical oceanographic conditions. Variations in temperature, ice, and current conditions are considered to be important. The first broad analysis of the hydrography, currents, and climatic variability of the Barents Sea was made by Helland-Hansen \& Nansen (1909). They stated that "it is to be expected that variations in the physical conditions of the sea have a great influence upon the biological conditions of various species of fishes living in the sea, and it might therefore also be expected that such variations are the primary cause of the great and hitherto unaccountable fluctuations in the fisheries". Since this work, many examples showing the influence of physical conditions on the ecosystem have been published.

Lee (1963) reviewed the documentation and data to date on the hydrography of the European Arctic, including the Barents Sea. Tantsiura (1959) and Novitskiy (1961) dealt with the currents of the Barents Sea. Sarynina (1969) was concerned with bottom water formation in Bjørnøyrenna (the Bear Island Channel), while Midttun (1985) discussed the formation of dense bottom water mainly in the eastern Barents Sea. Climatic variability has been studied by numerous authors during the last 20 years, for example
Midttun (1969), Bochkov (1976, 1982), Blindheim \& Loeng (1981), Dickson \& Blindheim (1984), Loeng \& Midttun (1984) and Sætersdal \& Loeng (1987). A brief review of the physical oceanographic conditions based on recent literature was made by Loeng (1989).

The present study briefly describes the general physical conditions in the Barents Sea and emphasises features that are important for biological investigations during the Pro Mare program.

\section{Currents}

In the southern part of the Barents Sea, the currents are directed toward the east, while in the north the current direction is westward or southwestward (Fig. 1).

The Barents Sea is a relatively shallow continental shelf sea with an average depth of $230 \mathrm{~m}$. The maximum depth of $500 \mathrm{~m}$ is found in the western part of the channel, Bjørnøyrenna. The shallowest areas are found on Spitsbergenbanken and in the southeastern part, around Kolgujev, where the depths are less than $50 \mathrm{~m}$. The bottom topography strongly influences the current conditions, especially in some bank areas. Most typical in this regard are the current conditions around Spitsbergenbanken and the large anti-cyclonic eddy created by Sentralbanken. Along the coast of northern Norway the topography also strongly 


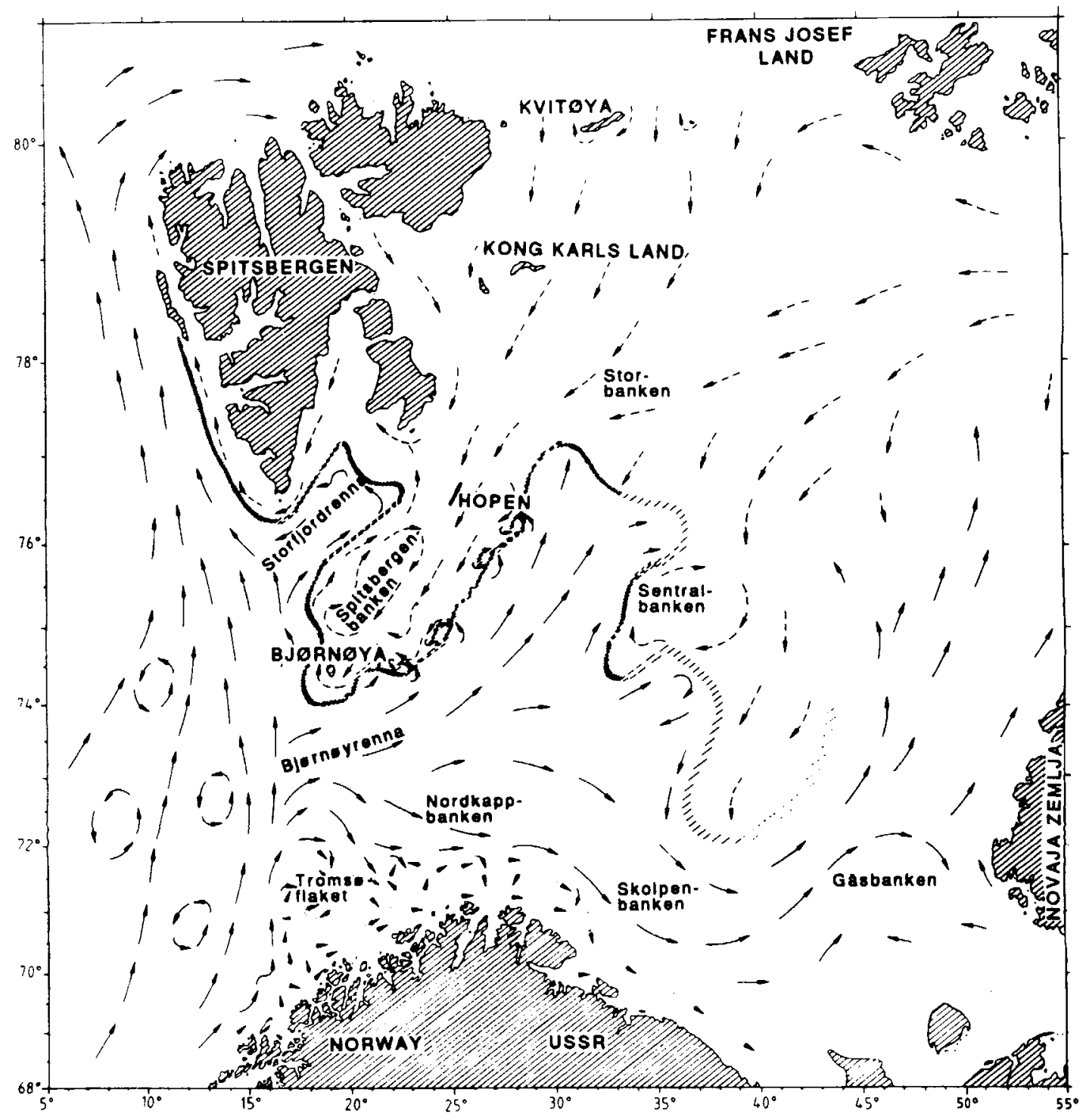

Fig. 1. Main features of the surface current systems in the Barents Sea. $\longrightarrow=$ Atlantic currents. $\cdots=$ Coastal currents. $-\rightarrow=$ Arctic currents. The hatched line indicates the mean position of the Polar Front (Locng 1989).

influences the currents, especially during winter when the stability is low (Sundby 1984). As shown in Fig. 1, the current turns around the bank of Tromsøflaket and then returns to the coast before leaving it again to the east.

The current directions indicated in Fig. 1 are also valid for the whole water column in most of the Barents Sea. Current measurements show only small changes in current direction with depth (Johansen et al. 1988; Loeng 1990). There are a few exceptions, however, such as in the areas west and south of Storbanken where Atlantic Water sinks below the lighter Arctic Water. Here the current direction in the deeper layer opposes the surface direction.

The Norwegian Coastal Current flows along the western and northern coast of Norway. During winter the current is deep and narrow, while during summer it is wide and shallow (Sætre \& Liøen 1971). When the current crosses the border 
to the USSR, it changes names to the Murman Coastal Current. It is supplied with low salinity water when it passes the White Sea.

The Norwegian Atlantic Current flows into the Barents Sea along Bjørnøyrenna and is called the Nordkapp Current. It divides into two main branches. One branch continues eastwards parallel to the coastal current system and also changes names to the Murman Current as it leaves the Norwegian area. During some years the influence of Atlantic Water in the Murman Current may be traced as far as the western shelf of Novaja Zemlja, while in other years, Atlantic Water hardly can be traced east of $40^{\circ} \mathrm{E}$ (Dickson et al. 1970).

The other main branch of the Atlantic Current turns north along the Hopen Trench and divides into smaller branches. Two of those continue as intermediate currents as they submerge below the lighter Arctic Water on their way north between Hopen and Storbanken, and eastwards between Storbanken and the Sentralbanken.

The influx of Arctic Water to the Barents Sea takes place along two main routes: firstly, between Spitsbergen and Frans Josef Land, and, more importantly, through the opening between Frans Josef Land and Novaja Zemija (Dickson et al. 1970). The main part of the first mentioned current flows as the East Spitsbergen Current southward along the coast of Spitsbergen. The current flowing southwestward south of Frans Josef Land, called the Persey Current, splits north of Sentralbanken. Tantsiura (1959) indicated that one branch turned south to Sentralbanken. Observations during the last years indicate, however, that this portion is probably small (Loeng 1989). The main part of the Persey Current goes southwestward along the eastern slope of the
Spitsbergenbanken as the Bjørnøya Current and plays an important role regarding the physical conditions in this area.

In discussing the cold water inflow to the Barents Sea, it should also be mentioned that a small inflow from the Kara Sea takes place south of Novaja Zemlja.

Little is known about the volume of water transported with the different currents. Blindheim (1989) calculated the inflow and outflow between Norway and Bjørnøya on the basis of current measurements and indicated a mean transport of about $3 \mathrm{~Sv}$ in, and about $1 \mathrm{~Sv}$ out, through this section ( $1 \mathrm{~Sv}$ (erdrup) $=10^{6} \mathrm{~m}^{3} \mathrm{~s}^{-1}$ ). This calculation requires another outflowing current, most likely located to the channel between Novaja Zemlja and Frans Josef Land. The transports in the straits south of Novaja Zemlja and between Frans Josef Land and Spitsbergen are probably small. The variability in the fluxes may be considerable. Calculations made by a numerical wind-driven model indicate fluctuations of the same magnitude as the mean transport ( $3 \mathrm{~Sv}$ ) in Bjørnøyrenna ( $\AA$ dlandsvik \& Loeng 1991 this volume). The variability in the North Atlantic Current from remote forcing is about as large (McClimans \& Nilsen 1990).

\section{Water masses}

Each of the three main water masses, Coastal Water, Atlantic Water, and Arctic Water, is linked to one of the main current systems. In a more comprehensive description, locally formed water masses must be considered (Table 1) as well as the extent of the different water masses (Fig. 2).

Table 1. Water masses in the Barents Sea.

\begin{tabular}{|c|c|c|c|}
\hline \multicolumn{2}{|l|}{ Names of the water masses } & \multicolumn{2}{|c|}{ Characteristics of the water masses } \\
\hline & & $\mathrm{T},{ }^{\circ} \mathrm{C}$ & $\mathbf{S}$ \\
\hline \multicolumn{4}{|l|}{ Main water masses: } \\
\hline Coastal Water & $(\mathrm{CW})$ & $>2.0$ & $<34.7$ \\
\hline (North) Atlantic Water & (NAW) & $>3.0$ & $>35.0$ \\
\hline Arctic Water & $(A W)$ & $<0.0$ & $34.3-34.8$ \\
\hline \multicolumn{4}{|l|}{ Locally formed water masses: } \\
\hline Meit Water & (MW) & $>0.0$ & $<34.2$ \\
\hline Spitsbergenbanken Water & (SBW) & $1.0-3.0$ & $<34.4$ \\
\hline Bottom Water & (BW) & $<-1.5$ & $>35.0$ \\
\hline Barents Sea Water & (BSW) & $-1.5-2.0$ & $34.7-35.0$ \\
\hline Polar Front Water & $(\mathrm{PW})$ & $-0.5-2.0$ & $34.8-35.0$ \\
\hline
\end{tabular}




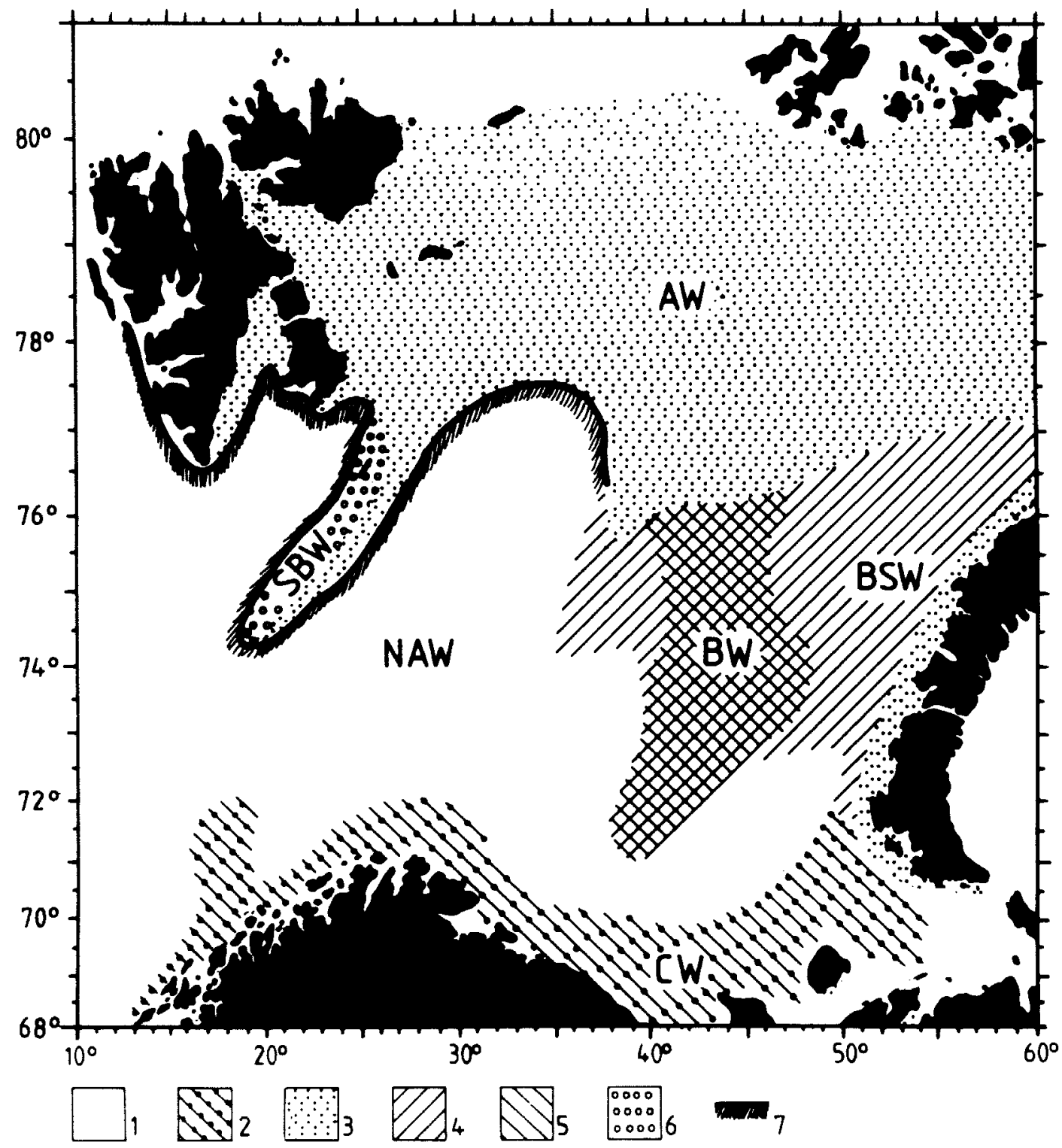

Fig. 2. Main features of the water masses distribution in the Barents Sea. $1=($ North) Atlantic Water (NAW); $2=$ Coastal Water $(\mathrm{CW}) ; 3=$ Arctic Water $(\mathrm{AW}): 4=$ Barents Sca Water $(B S W): 5=$ Bottom Water $(\mathrm{BW}): 6=$ Spitsbergenbanken Water $($ SBW $)$; $7=$ Polar Front.

According to Helland-Hansen \& Nansen (1909), the Atlantic Water is defined by salinity higher than 35.0. Between Norway and Bjørnøya the temperature varies from 3.5 to $6.5^{\circ} \mathrm{C}$, depending both on seasonal and interannual variations. Both the temperature and salinity decrease north and eastwards and, relatively often, water with salinity down to 34.95 is classi- fied as Atlantic Water. The temperature and salinity since 1970 is shown in Fig. 3 in two sections, one from Fugløya ( $\mathrm{N} 70^{\circ} 30^{\prime}$, E $20^{\circ} 00^{\prime}$ ) to Bjørnøya, and the other from Vardø and northward (along $\mathrm{E} 31^{\circ} 13^{\prime}$ ). The values are calculated for the depth layer $50-200 \mathrm{~m}$, which contains Atlantic Water. Both the large variability in temperature and salinity as well as the decrease in 

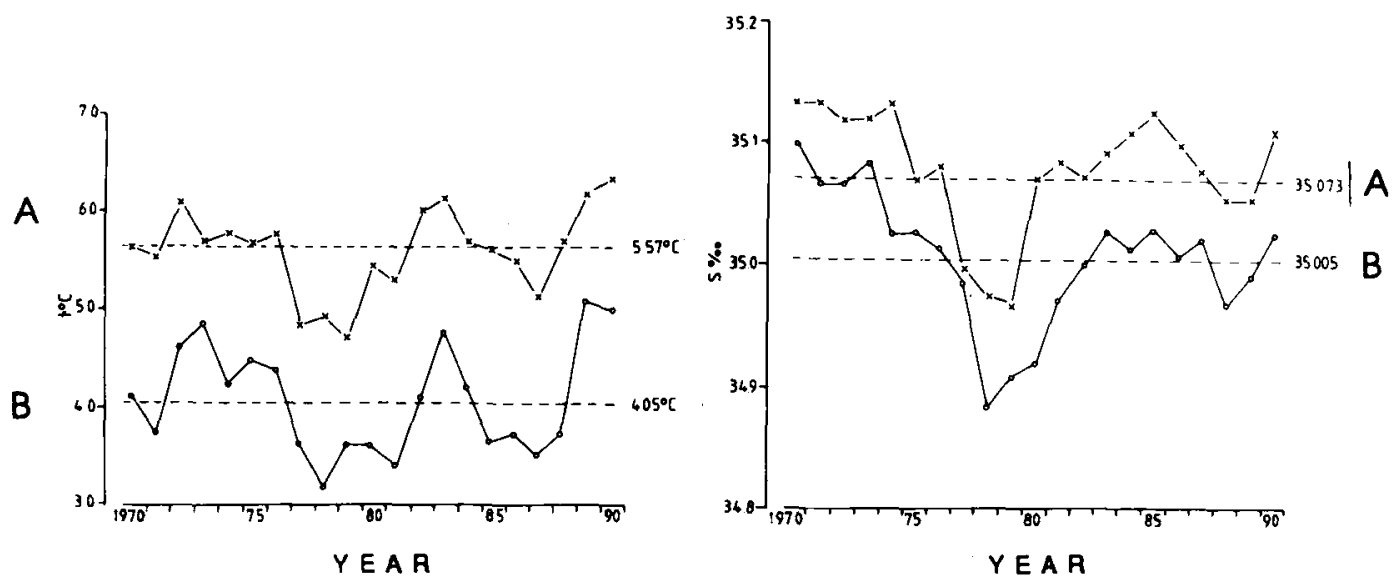

Fig. 3. Mean temperature and salinity in the depth layer 50-200 $\mathrm{m}$ in the section Fugløya - Bjørnøya (A) and Vardø-N (B) in late August and early September. The mean values are calculated for that part of the sections which are occupied by Atlantic Water.

values from west to east are seen. A clear demonstration of the variations in salinity over long periods is given by Dickson \& Blindheim (1984).

The Coastal Water has almost the same temperature as the Atlantic Water, but the salinity is $<34.7$. The Coastal Water is, unlike the other main water masses in the Barents Sea, vertically stratified the entire year, at least along the Norwegian coast. Farther east, in the shallow areas around Kolgujev, the stratification is almost broken down during winter.

The Arctic Water also has low salinity, but it is most easily characterised by the temperature $<0^{\circ} \mathrm{C}$ (Table 1). The core of the Arctic Water, however, has the temperature $<-1.5^{\circ} \mathrm{C}$ and salinity between 34.4 and 34.7. During winter, the Arctic Water occupies the upper $150 \mathrm{~m}$ of the water column, while during summer, it is covered by melt water with a thickness of $5-20 \mathrm{~m}$. The melt water has a low salinity, varying from below 31.0 and up to 34.2 . It has a positive temperature due to heating from the atmosphere and it is separated from the Arctic Water by a sharp transition layer. The melt water is usually found north of the Polar Front. In cold years, however, with very heavy ice formation, ice can drift south of the Polar Front. The ice starts to melt due to the heat from the Atlantic Water; it will then form a thin surface layer of melt water.

In the case of locally formed water masses (Table 1), the bottom water is formed at various places, and also by different processes. The formation of bottom water at the shallow shelf of
Novaja Zemlja and also at Sentralbanken takes place in two steps. First the density is increased due to cooling of the water. This process becomes progressively slower as the temperature approaches freezing point. Secondly, beginning with the formation of ice, the density increases because of increased salinity resulting from brine rejection to the water (Midttun 1985). The temperatures of the bottom water formed on the shelf of Novaja Zemlja may reach $-1.9^{\circ} \mathrm{C}$ and the salinity may be as high as 35.2 . Bottom water with somewhat lower salinity is formed on Sentralbanken during winter. The amount of bottom water formed may vary from year to year (Midttun \& Loeng 1987). According to Sarynina (1969), bottom water is also formed along the Polar Front at the southeastern slope of Spitsbergenbanken, but this water has other characteristics. A part of the bottom water formed on Sentralbanken also leaves the Barents Sea along Bjørnøyrenna (Blindheim 1989). The bottom water in Bjørnøyrenna is not indicated in Fig. 2.

The Barents Sea Water found in the eastern Barents Sea is transformed Atlantic Water mixed with Arctic Water. The Atlantic Water in the eastern Barents Sea changes its characteristics due to the processes linked to ice formation and melting (Midttun 1985). The distribution may therefore vary with variations in the ice coverage. In the eastern basin, the Barents Sea water is found above the bottom water (Fig. 2). The Polar Front Water, which is a mixture of Atlantic and Arctic waters, has almost the same characteristics 
as the Barents Sea Water (Table 1). but it is found in the western Barents Sea.

On the central part of Spitsbergenbanken there is a water mass with rather low salinity and a temperature between $1-3^{\circ} \mathrm{C}$ during the summer. This is a mixture between Arctic Water and melt water which has been heated by the atmosphere during the summer. The water mass is found only in the large gyre on the central part of the bank. Between Spitsbergenbanken Water and the Arctic Water to the east, there is a front, called the Summer Front. The distribution of water masses and fronts on the eastern slope of Spitsbergenbanken during the summer is illustrated in Fig. 4. The real picture is even more complex, with many small eddies in the frental areas (Fig. 1). In addition, large seasonal variation occurs where both the Spitsbergenbanken Water and the Summer Front disappear during the cold season.

\section{Vertical stratification}

The stratification of water masses in spring exerts a very strong influence on the development of spring blooms. Further on, the vertical mixing processes that take place during the winter are important in transporting nutrient rich water to the surface layer. Both the stratification and the mixing processes may develop differently in the various water masses.

During the winter, vertical mixing due to cooling of the water masses takes place over the entire Barents Sea. In the Atlantic Water, the water

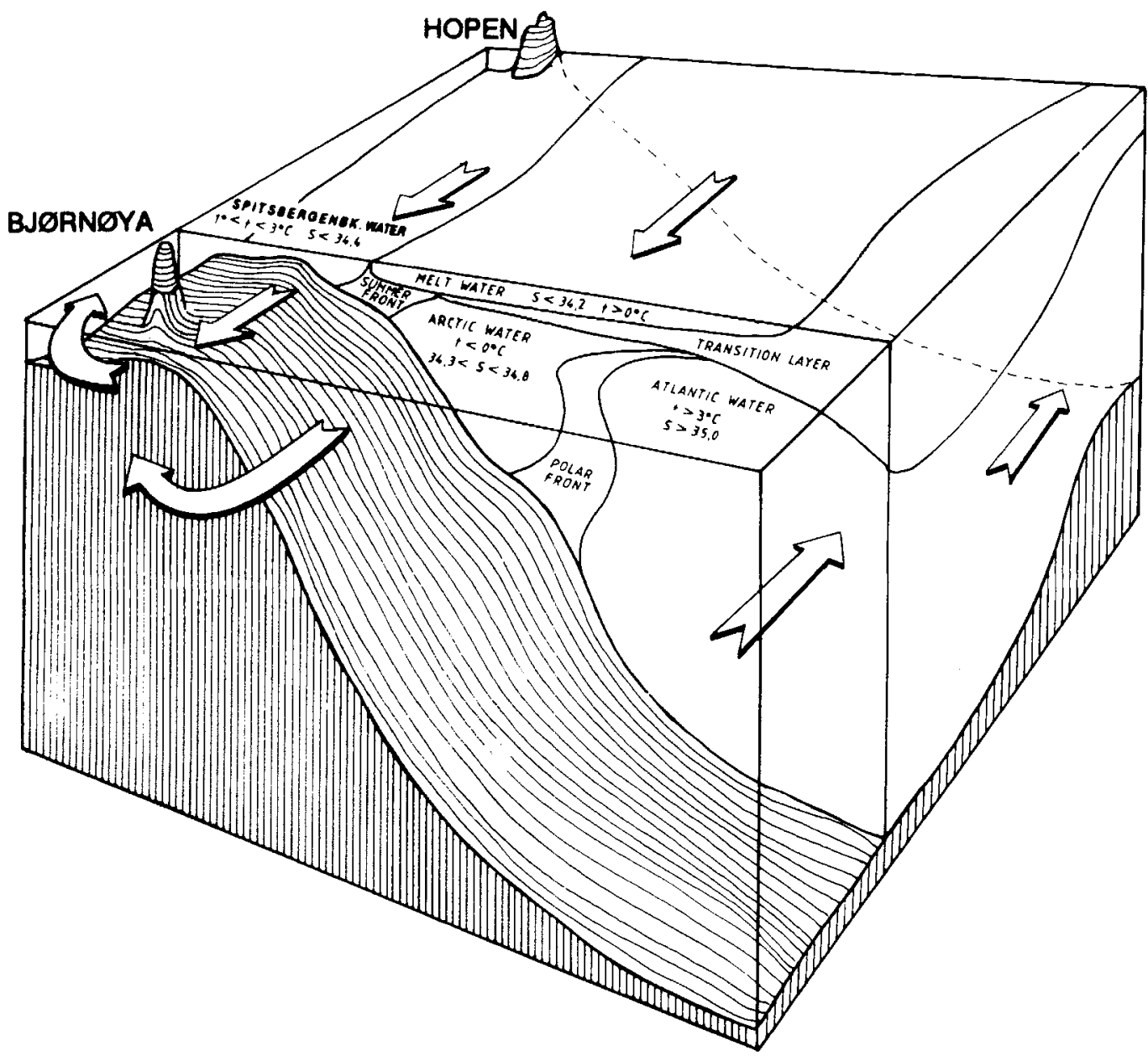

Fig. 4. Typical water mass distribution at the eastern slope of Spitshergenbanken during summer and autumn 

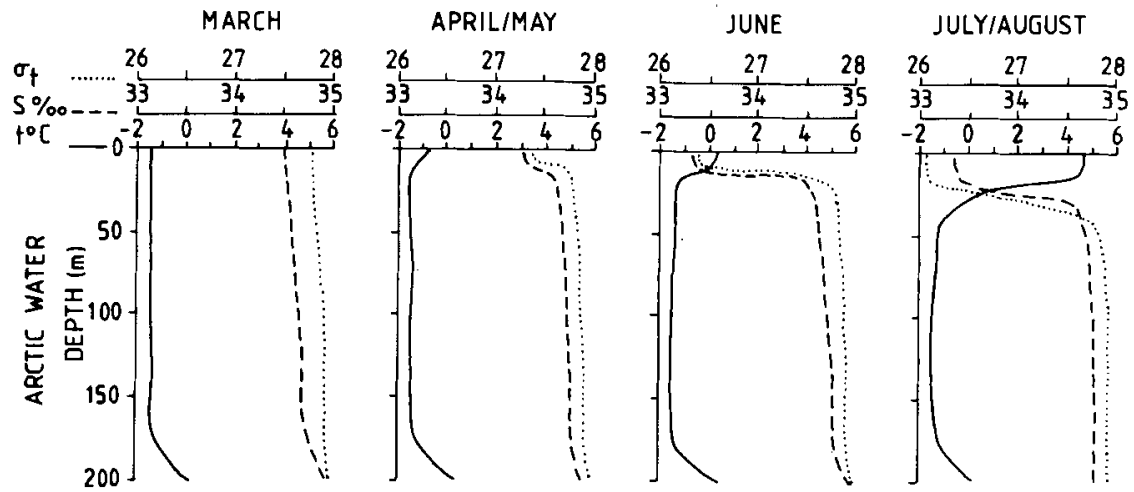

\section{EARLY OCTOBER}
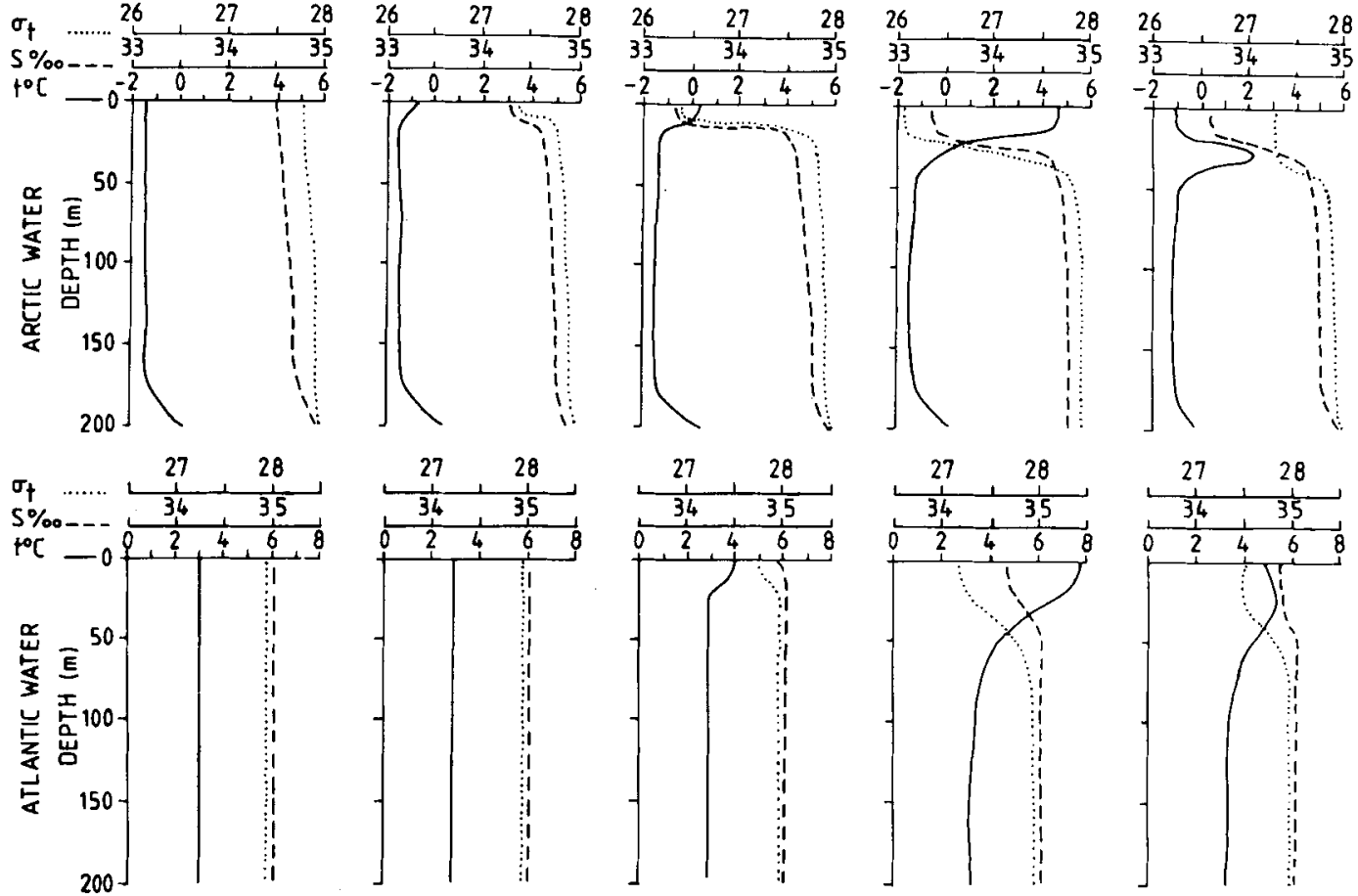

Fig. 5. Illustration of the vertical distribution of temperature, salinity and sigma-t from the surface to $200 \mathrm{~m}$ in Arctic and Atlantic water masses. The illustration is based on several years of observations.

column may be homogeneous down to $2-300 \mathrm{~m}$ due to vertical convection. In areas that have been covered by ice in the summer, the cooling process alone is not enough to create deep convection since the salinity gradient is too large. However, freezing of the ice with the rejection of brine will break down the salinity gradient, or at least the transition layer between the melt water at the surface and the Arctic Water below. Observations in areas up to more than $200 \mathrm{~km}$ behind the ice border in 1983 showed a constant temperature down to $150 \mathrm{~m}$, while a salinity gradient maintained a weak vertical stability (Gjøsæter et al. 1983).

The stability in the central and northern Barents Sea is caused by two mechanisms: ice melt and warming of the surface layer. Melting of ice can again be separated into two categories. In cold years with heavy ice formation, ice can drift south of the Polar Front and begin to melt due to the heat from the Atlantic Water. This melting, which initially is more or less independent of atmospheric conditions, produces an upper layer with reduced salinity. This may give rise to an early stabilisation of the upper layer, and consequently an early phytoplankton bloom (Skjoldal et al. 1987). Melting of ice in the Atlantic Water occurred in the cold years 1979 and 1981, but not during the Pro Mare period. North of the Polar Front, the melting of ice begins when the air temperature rises above freezing. In the ice free areas, stability starts to form when heating from the atmosphere begins in May-June. The difference between the development of stability in the Arctic and Atlantic Waters is illustrated in Fig. 5.

When the ice starts to melt, usually in late April or early May, a thin layer of melt water is progressively formed. In the beginning the melt water layer is about $5 \mathrm{~m}$ thick, but the thickness increases to $15-20 \mathrm{~m}$ during the summer and early autumn. Depending on the amount of ice, the melt water may have a salinity varying from below 31.0 up to 34.2 , while the temperature increases during summer to $4-5^{\circ} \mathrm{C}$. The melt water layer is always well-mixed without any stratification. It 

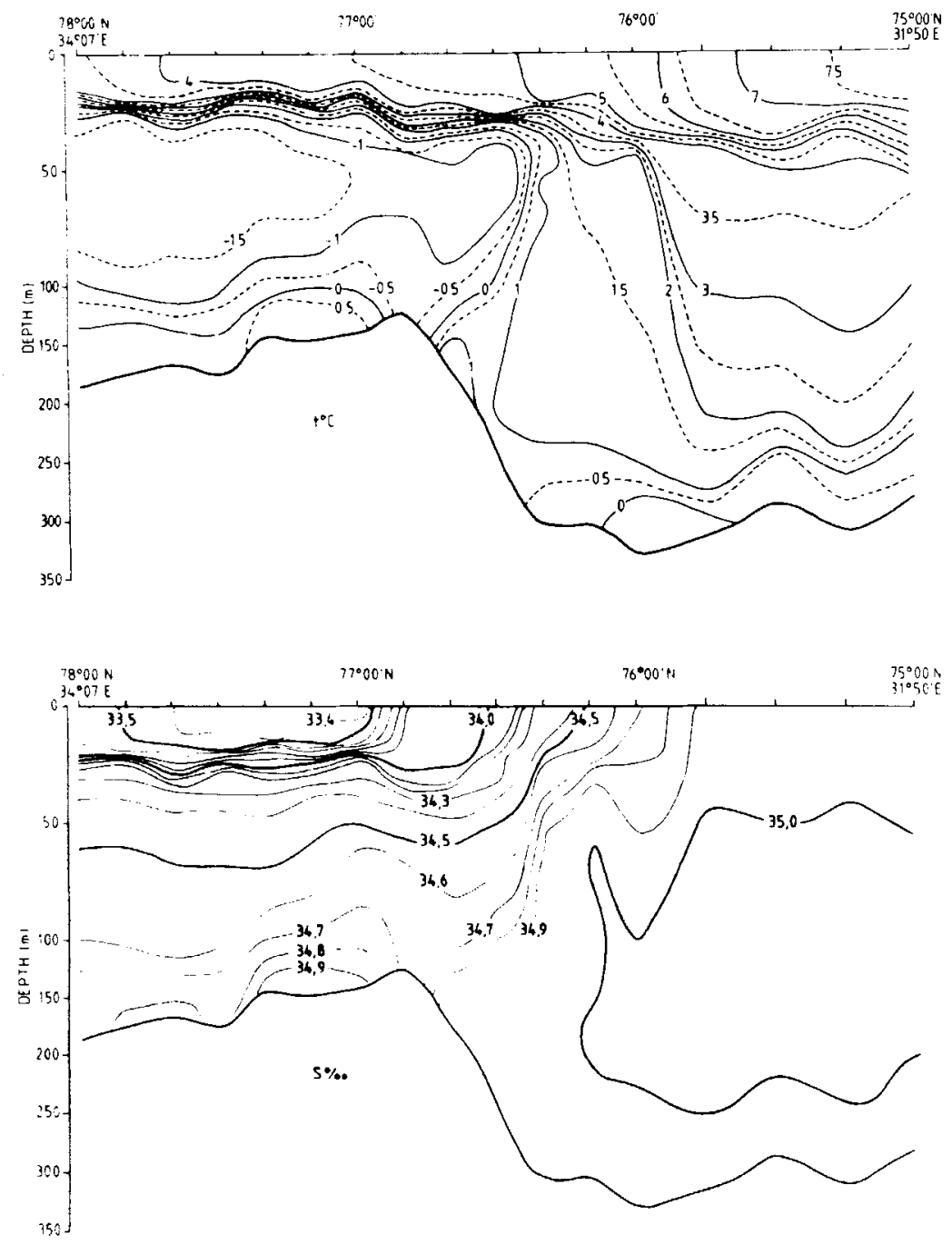

Fig. 6. Temperature. salinity and sigma-t observed in a vertical section from the Hopen Trench to Storbanken in autumn 1984. (Hassel et al. 1984)

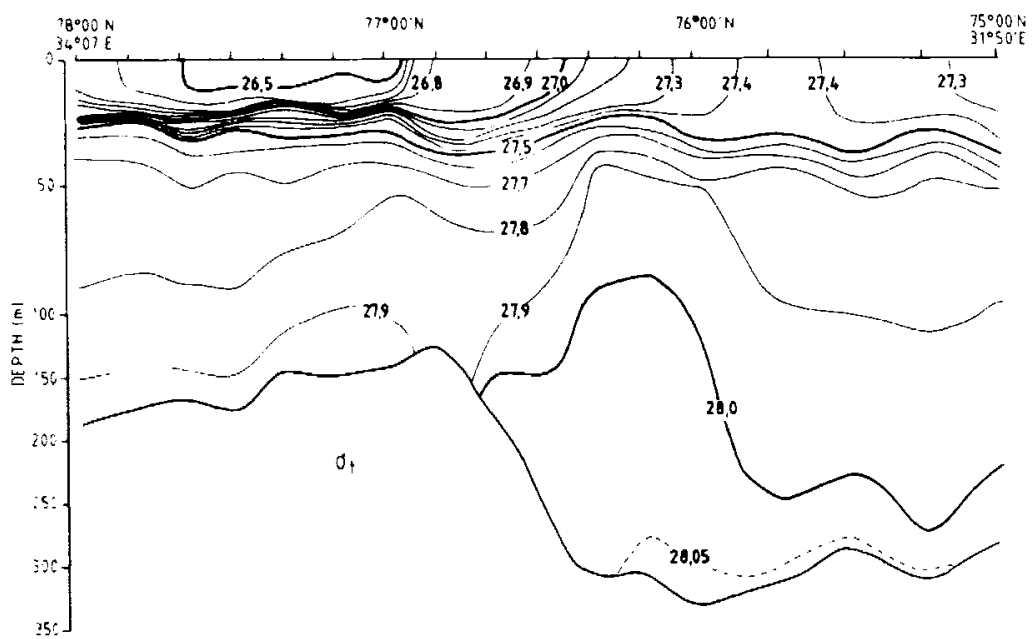


is separated from the underlying Arctic Water (occasionally Atlantic Water) by a sharp transition layer. The transition layer is usually thin; in the early spring it is less than $5 \mathrm{~m}$, increasing to a maximum of $15 \mathrm{~m}$ in the autumn. This layer never breaks down, and the vertical transport of properties through the transition layer is insignificant. In the Arctic Water below the transition layer there is a weak stratification, sufficient for primary production because of a salinity gradient, as demonstrated in Fig. 6. This salinity gradient is broken down during the winter with very heavy ice formation. Also shown in Fig. 6 is the difference between the vertical distribution of temperature and salinity in the Atlantic and Arctic waters in the autumn, and consequently a difference in vertical stratification.

In the Atlantic Water, which has not been covered by ice, the stratification starts to develop when the sun begins to warm the surface layer. The stratification progresses very slowly, and in the early spring there is usually a smooth gradient from the surface and down to $10-20 \mathrm{~m}$ (Fig. 5). During the summer the warming of the water column reaches down to $50-60 \mathrm{~m}$ by means of turbulent mixing. Meanwhile a vertical homogeneous surface layer with a thickness of about $10 \mathrm{~m}$ is formed (Fig. 6). The stratification in the underlying Atlantic Water is weaker than in the Arctic Water.

The Coastal Water retains a weak vertical stability throughout the winter. In the spring and summer, the stratification increases because of the supply of fresh water and increased temperature. Since the Coastal Water is always stratified, the phytoplankton bloom starts as soon as the light intensity is sufficient. In the Barents
Sea the phytoplankton bloom usually starts at approximately the same time in the Coastal Water and at the ice edge. In the Atlantic Water where the stratification starts later, the blooming also starts later (Rey \& Loeng 1985). In years when the stability is formed early due to ice melting in the Atlantic Water, an early and intensive bloom occurs at the ice edge (Rey \& Loeng 1985; Skjoldal et al. 1987).

\section{Climatic variability}

In early studies of the climate of the Barents Sea, the climatic variability was linked to the ice conditions. Chavanne (1875) gave the first broad scientific review of the ice conditions, including observations back to 1553 . Helland-Hansen \& Nansen (1909) were among the first to include changes in the oceanographic conditions and to make comparative studies in hydrographic and ice conditions. Since 1960 , several papers have dealt with the variability in the Barents Sea climate, and a few have also considered the causes for the variability.

A general conclusion has been that climatic variations in the Barents Sea depend mainly on the activity and properties of the inflowing Atlantic Water. Already in 1909, Helland-Hansen \& Nansen (1909) suggested that climatic variations in the Barents Sea probably are of advective nature. They observed a time lag of one year between Lofoten and the Kola-section. Climatic variations can therefore be recorded in sections crossing the inflowing Atlantic Water. Investigations so far show similar variability in all sections crossing the Atlantic inflow, perhaps with a

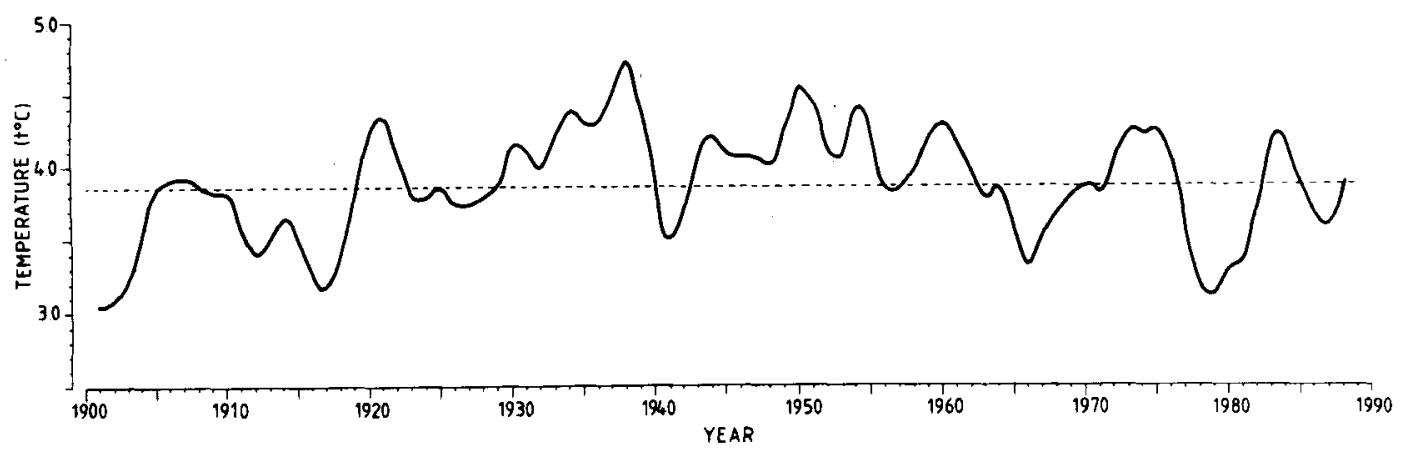

Fig. 7. Three years running average of yearly temperature anomalies in the Kola-section (along $33^{\circ} 30^{\prime} \mathrm{E}$ ) during the period $1900-$ 1990, based on data from Bochkov (1982) and from PINRO, Murmansk (pers. commun.). 
time lag of about half a year between the westèrn and eastern parts of the Barents Sea (Loeng et al. 1983).

The longest time series of temperature is the Soviet recording in the Kola-section, the observation series began already in 1900 , but two periods were missing, 1906-1919 and 1941-1944. Bochkov (1982) has filled in these two gaps by a combination of interpolation and other observations. The period 1906-1919 was measured quarterly, while the rest of the time series has monthly values. Fig. 7 shows a three-year running mean for the entire period $1900-1990$. The main part of the period 1900-1920 was cold. The temperature increased during the period 1917-1920, and the first half of the 1920's was warm, while the second part had temperatures lower than normal. Most of the period 1930-1965 has temperatures above the mean value, with a maximum in 1938 . The last 25 years have shown a larger variability.

A more detailed picture of the temperature variations during the last 30 years is shown in Fig. 8. The 1960 's were characterised by large fluctuations. The period $1970-76$ was warm, while the second half of that decade was characterised by low temperatures. Throughout 1982 there was a strong temperature increase, and then there were a couple of warm years. The Pro Mare period consequently started with a warm year. while the rest of that period had temperatures slightly below average. At the very end of the period, there was a very strong temperature increase in the western and central parts of the Barents Sea, which started in March 1989.

The ice coverage also shows large variations which seem to follow the temperature fluctuations (Fig. 8). Compared to 1979, which was a heavy ice year (Fig. 8), the Pro Mare period 1984-1989 had rather little ice (Fig. 9). The variations of the sea ice cover may be classified according to three different types: 1) short-term variations, which take place within periods from a few hours to one month; 2) seasonal variability, which in its broad features is similar from year to year with maximum and minimum coverage in March-May and September (Loeng 1979; Vinje \& Kvambekk 1991 this volume); and 3 ) large interannual variations. Cyclic variations of 3 to 5 years' duration have been proposed by several authors (Kissler 1934; Lunde 1965), but the documentation is not convincing. The same cycle seems to occur in the temperature observation from the Kola-section. Recent analysis of the time series from the Kola-section back to 1920 indicates a main period of 3.2 years.

Concerning the causes of the considerable interannual variations in the sea ice conditions, knowledge is still sparse. During the winter and early spring, the position of the ice edge follows the Polar Front in the Barents Sea. It is then plausible that changes in oceanic circulation cause

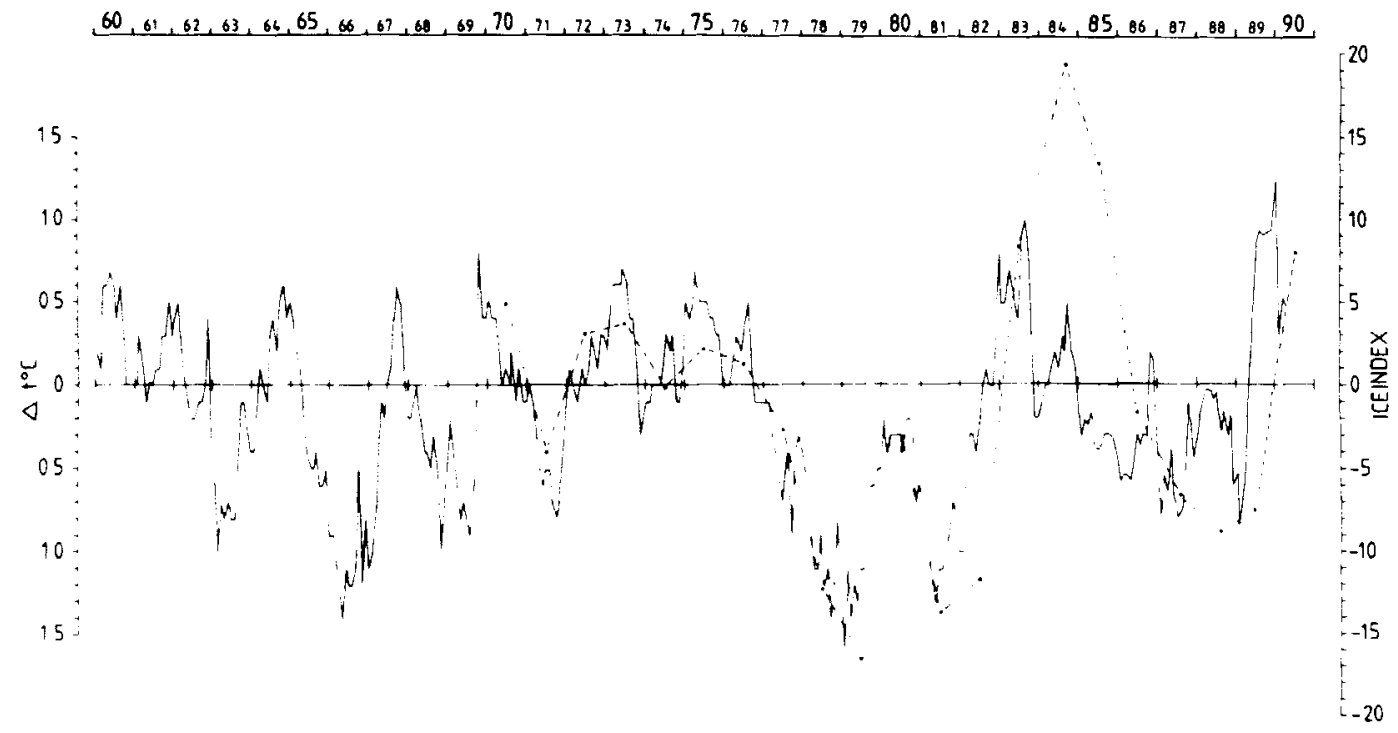

Fig. 8. Temperature anomalies in the Kola-section (along 33 $30^{\prime}$ E) during the period 1960 -1990 (solid line) together with the ice index during the period 1970-1990) (broken line) (Loeng 1989). 


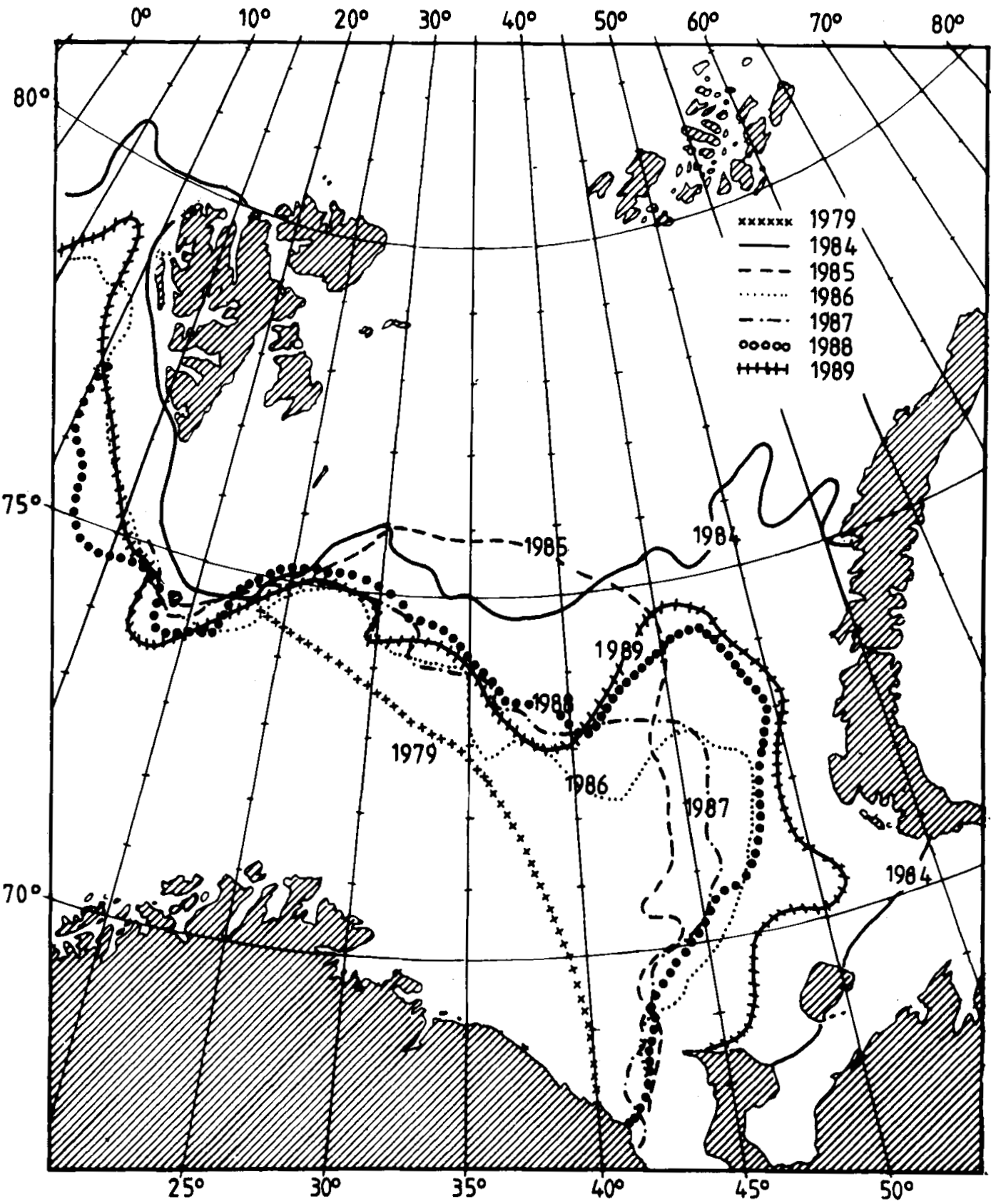

Fig. 9. Maximum ice coverage in the Barents Sea during winter in the Pro Mare period 1984-1989. The maximum coverage from 1979 is included for comparison.

changes in ice conditions, as first claimed by Helland-Hansen \& Nansen (1909). During rapid temperature increases, as in $1982-83$ and 1989 , the decrease in ice coverage seems to be delayed hv nne vear (Fig. 8). The meiting of ice during summer is independent of the oceanic conditions, as it depends only on meteorological conditions (Loeng \& Vinje 1979).

The variability of the Barents Sea climate may be explained by similar fluctuations in the proper- 

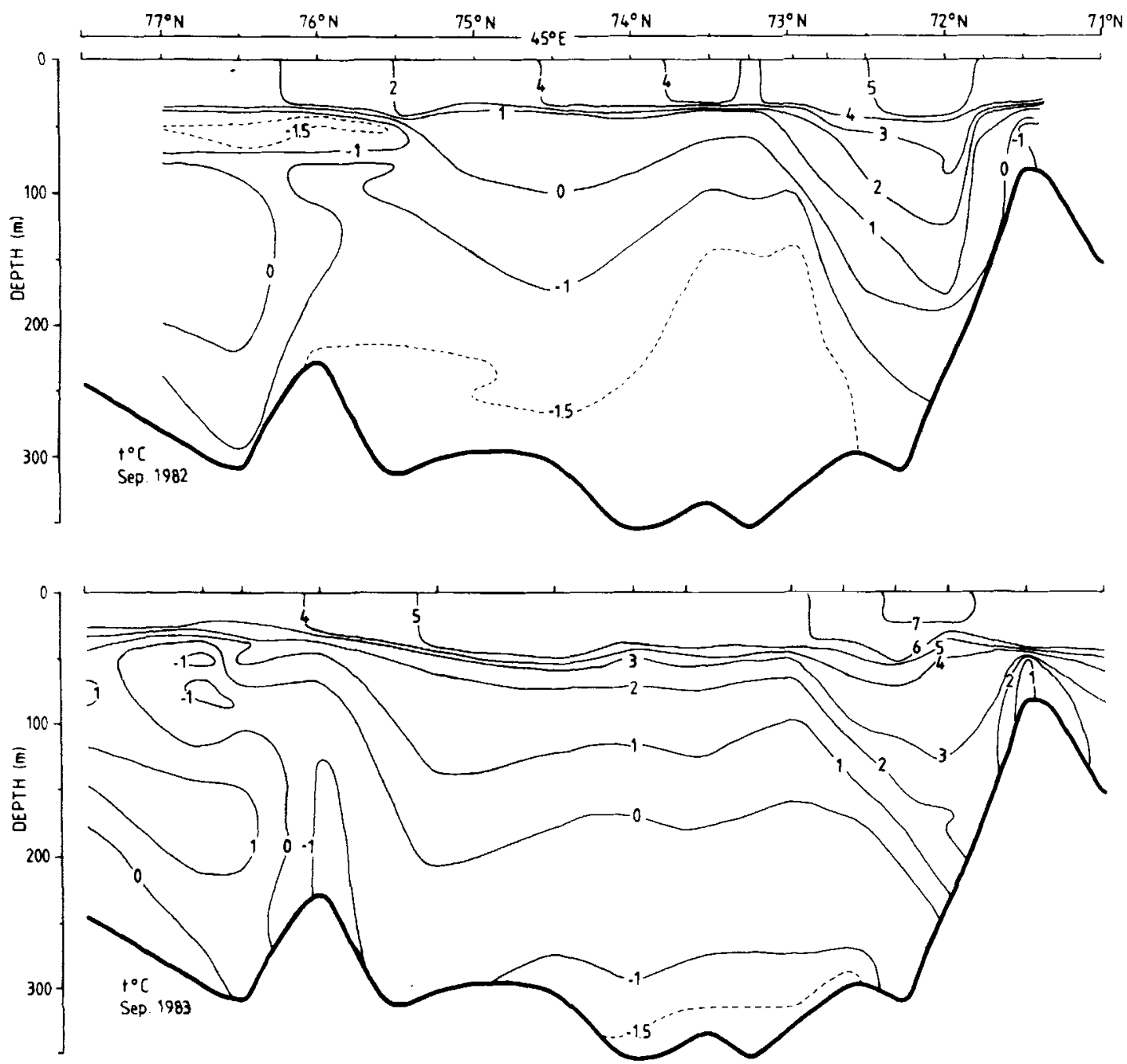

Fig. 10. Temperature in the meridional section of $45^{\circ} \mathrm{E}$ in September 1982 and 1983 (Midttun \& Loeng 1987).

ties of the inflowing water. This means that an almost constant transport is bringing in Atlantic Water with changing temperature and salinity. But the variations can just as well be a result of variations in the volume flux with stable properties. Most likely there is a combination: that is. a large volume flux corresponds to higher temperature than a small flux. The variability in the currents may be explained by external forcing. but may also be a result of processes taking place in the Barents Sea itself (Midttun \& Loeng 1987).

One process of importance in the Barents Sea is the formation and outflow of Bottom Water from the eastern basin. During the winter, water of high density is formed as a result of cooling and ice formation, a process described in detail by Midttun (1985). The Bottom Water formed over Sentralbanken and the shelf area of Novaja Zemlja flows into the eastern basin, which may occasionally fill entirely up with this water. The rate of production of dense bottom water may vary from year to year, and more than one year may be required before the eastern basin is filled after a massive purging. Most of this dense bottom water mass leaves the Barents Sea through the strait between Novaja Zemlja and Frans Josef Land. The water masses which in this way leave the sea have to be replaced by inflowing water 
from the west. The outflowing volume may vary considerably from year to year, and so will the corresponding inflow. As described by Midttun (1985) and Midttun \& Loeng (1987), this kind of outflow from the eastern basin is thought, in a certain sense, to be driven by itself.

The exchange of water masses in the eastern basin from 1982 to 1983 is shown in Fig. 10. The main part of the cold water observed in 1982 has been replaced with water of a higher temperature in 1983. The same phenomenon occurred between 1989 and 1990 (unpubl. material). With only one observation each year, it is impossible to say exactly when and how long time this process takes. From the temperature observations in the Kola-section, however, it appears that the process takes place over a period of at least half a year. Observations from the different sections in the Barents Sea indicate that most of the large temperature increases due to increased inflow begin mainly in late autumn or early winter. The timing of major inflow events in relation to the seasonal vertical migration of Calanus finmarchicus in the Norwegian Sea would determine whether this water would be poor or rich in zooplankton. The variability in the Atlantic inflow is therefore important in explaining the large interannual variation in the zooplankton biomass in the southern Barents Sea (Skjoldal \& Rey 1989).

Ådlandsvik (1989) and Ådlandsvik \& Loeng (1991) have shown that the variability in the Atlantic inflow is closely related to wind conditions. The warm periods in the Barents Sea are related to a stable low pressure situation in the area, while low temperature is linked to high pressure (Ådlandsvik \& Loeng 1991). Related to the strong temperature increase in 1982-83, was the maximum transport of Atlantic Water into the Barents Sea due to wind conditions (Ådlandsvik 1989). It is then easy to believe that the pressure created by the wind-driven inflow will push the Bottom Water in the eastern basin out of the Barents Sea. Results from a laboratory model support this assumption (McClimans \& Nilsen 1990). The combination of an increased inflow caused by atmospheric circulation and the following outflow of Bottom Water allows large and rapid temperature increases as observed in 198283 and 1989 (Fig. 7).

Acknowledgements. - I thank H. Kismul for designing Fig. 4. Some of the results presented have been obtained through the
Pro Mare programme with financial support from the Norwegian Fisheries Research Council (NFFR).

\section{References}

Ådlandsvik, B. 1989: Wind-driven variations in the Atlantic inflow to the Barents Sea. Coun. Meet. Int. Coun. Explor. Sea, 1989 (C:18), 1-13.

Ådlandsvik, B. \& Loeng, H. 1991: A study of the climatic system in the Barents Sea. Pp. $45-49$ in Sakshaug, E., Hopkins, C. C. E. \& Øritsland, N. A. (eds.): Proceedings of the Pro Mare Symposium on Polar Marine Ecology, Trondheim, 12-16 May 1990. Polar Research 10(1).

Blindheim, J. 1989: Cascading of Barents Sea bottom water into the Norwegian Sea. Rapp. P.-v. Réun. Cons. Int. Explor. Mer 188, 49-58.

Blindheim, J. \& Loeng, H. 1981: On the variability of Atlantic influence in the Norwegian and Barents Seas. Fisk. dir. Skr. Ser. Havunders. 17, 161-189.

Bochkov, Yu.A. 1976: On the effect of solar activity of various periodicity on the thermal regime of the Barents Sea. Comm. Meet. Int. Counc. Explor. Sea. 1981(C:19), 1-19.

Bochkov, Yu.A. 1982: Water temperature in the $0-200 \mathrm{~m}$ layer on the Kola-Meridian in the Barents Sea, 1900-1981. Sb. Nauchn. Trud. PINRO, Murmansk, 46, 113-122 (in Russian).

Chavanne. J. 1875: Die Eisverhaltnisse in arktischen Polarmeere und ihre periodischen Veränderungen. Geographie und Erforschung der Polar Regionen, 108, 134-142, 245-280.

Dickson, R. \& Blindheim, J. 1984: On the abnormal hydrographic conditions in the European Arctic during the 1970's. Jens Smed Volume, Rapp. P.-v. Réun. Cons. Int. Explor. Mer 185, 201-213.

Dickson, R. R., Midttun, L. \& Mukhin, A. I. 1970: The hydrographic conditions in the Barents Sea in August-September 1965-1968. Pp. 3-24 in Dragesund, O. (ed.): International O.group fish surveys in the Barents Sea 1965-1968. Int. Coun. Explor. Sea. Cooperative Res. Rep., Ser. A, No. 18

Gjøsæter, H. , Hassel, A., Loeng, H., Rey, F. \& Skjoldal, H. R. 1983: Preliminære resultater fra tokt i Barentshavet med M/S 'Lance' og F/F 'G.O. Sars' i mai/juni 1983. Havforskningsinstituttet, Rapport FO 8310. 21 pp. + appendix (in Norwegian), Bergen.

Hassel, A., Loeng, H., Rey, F. \& Solberg, T. 1984. Resultater fra tokt med F/F G.O. Sars i Barentshavet 4-19.8.1984. Havforsknings-instituttet, Rapport FO 8410,32 pp + appendix (in Norwegian), Bergen.

Helland-Hansen, B. \& Nansen, F. 1909: The Norwegian Sea. Fisk. dir. Skr. Ser. Havunders. 2(2), 1-360.

Johansen, Ø., Mathisen, J. P. \& Steinbakke, P. 1988: Environmental data collection in the Barents Sea. Report no. $O C E$ 88059. Oceanor. Trondheim. 58 pp. + appendix.

Kissler, F. 1934: Eisgrensen und Eisverschiebungen in der Arktis zwischen $50^{\circ}$ West und $105^{\circ}$ Ost im 34-jahrigen Zeitraum 1898-1931. Beitr. Geophys. 42 (1), 12-55.

Lee, A. 1963: The hydrography of the European Arctic and Subarctic seas. Oceanogr. Mar. Biol. 1, 47-76.

Loeng, H. 1979: A review of the sea ice conditions of the Barents Sea and the area west of Spitsbergen. Fiskenog Havet. 1979 (2), 29-75 (in Norwegian, abstract in English). Loeng, H. 1989: Ecological features of the Barents Sea. Pp 327-365 in Rey, L. and Alexander, V. (eds.): Proc. 6th Conf. Comité Arct. Internat., 13-15 May 1985. E. J. Brill, Leiden. 
Loeng. H. 1990: Current measurements southeast of Sentralbanken in the Barents Sea. Institute of Marine Research. Report FO $9002.18 \mathrm{pp} .+4$ appendix. Bergen.

Loeng, H. Midtun, L. 1984: Climatic variations in the Barents Sea during the 1970's. Coun. Meet. Int. Coun. Explor. Sea, 1984 (Gen:15), 1-10.

Loeng, H. \& Vinje. T. 1979: On the sea ice conditions in the Greenland and Barents Seas. Pp. 163-174 in Anon. (ed.): POAC 79. Proc. 5th Internat. Conf. Port and Ocean Engineering Under Arctic Conditions. The Norwegian Institutc of Technology, Trondheim

Loeng, H.. Nakken. O. \& Raknes. A. 1983: The distribution of capelin in the Barents Sea in relation to water temperature in the period 1974-1982. Fiskenog Havet., 1983 (I), 1-17 (in Norwegian, abstract in English)

Lunde, T. 1965: Ice conditions at Svalbard 1946-1963. Norsk Polarinst. Árb. 1963, 61-80.

McClimans, T. A. \& Nilsen, J. H. 1990: A laboratory simulation of the ocean currents of the Barents Sea during 1979-1984. Norwegion Hydrotechnical Laboratory, report STF6O A90018. 59 pp. Trondhcim.

Midttun. L. 1969: Variability of temperature and salinity at some localities off the coast of Norway. Prog. Oceanogr. 5 . 41-54.

Midtun. L. 1985: Formation of dense bottom water in the Barents Sea. Deep-Sea Res 32, 1233-1241.

Midttun, L. \& Loeng, H. 1987: Climatic variations in the Barents Sea. Pp. 13-27 in Loeng. H. (cd.): The effect of oceanographic conditions on distribution and population dynamics of commercial fish stocks in the Barents Sea. Proc. 3rd Soviet-Norwegian Symp., Murmansk, 26-28 May 1986. Institute of Marine Research, Bergen.

Novitskiy. V. P. 1961: Permanent currents of the northern Barents Sea. Trudy Gos. Okeanogr. Inst. 64. 1-32 (in Russian).

Rey. F. \& Locng. H. 1985: The infuence of ice and hydrographic conditions on the development of phytoplankton in the Barents Sea. Pp. 49-63 in Gray, J. S. \& Christiansen, M. E. (eds.): Marine Biology of Polar Regions and Effects of Stress on Marine Organisms. John Wiley \& Sons Lid, London.

Satersdal. G. \& Loeng. H. 1987: Ecological adaptation of reproduction in Northeast Arctic cod. Fish. Res. 5, 253-270.

Satre. R. \& Ljøen, R. 1971: The Norwegian Coastal Current. Pp. 515-535 in Anon. (ed.): Proc. Ist Internat. Conf. Port and Ocean Engineering under Arctic Conditions. Volume II Technical University of Norway. Trondheim.

Sarynina. R. N. 1969: Conditions of origin of Cold Deep-Sea Waters in the Bear Island Channel. Coun. Meet. Int. Coun. Explor. Sea 1969 (Symp:28). 1-8.

Skjoldal. H. R.\& Rey, F. 1989: Pelagic production and variability of the Barents Sea ecosystem. Pp. 242-286 in Sherman, K. \& Alexander. L. M. (eds.): Biomass yields and geography of large marine ecosystems. AAAS Selected Symposium 111. Westview Press, Boulder. Colorado, USA.

Skjoldal. H. R. . Hassel, A., Rey, F. \& Loeng, H. 1987: Spring phytoplankton development and zooplankton reproduction in the central Barents Sea in the period 1979-1984. Pp. 5989 in Loeng. H. (ed.): The effect of oceanographic conditions on distribution and population dynamics of commercial fish stocks in the Barents Sea. Proc. 3rd Soviet-Norwegian Symp., Murmansk. 26-28 May 1986. Institute of Marine Research, Bergen.

Sundby. S. 1984: Influence of bottom topography on the circulation at the continental shelf off Northern Norway. Fisk dir. Skr. Ser. Havunders. 17, 501-519.

Tantisiura. A. 1. 1959: About the currents in the Barents Sca. Trudy Polyar. Nauchno-issled. Inst. Morsk. Ryb. Knoz. Okeanogr. $11,35-53$ (in Russian).

Vinje. T. \& Kvambekk, §.S. 1991: Barents Sea drift ice characteristics. Pp. 59-68 in Sakshaug, E., Hopkins, C. C. E. \& Øritsland. N. A. (eds.): Proceedings from the Pro Mare Symposium on Polar Marine Ecology, Trondheim, 12-16 May 1990. Polar Research 1011). 